\title{
PENGARUH CORPORATE GOVERNANCE DAN LEVERAGE PADA AGENCY COST
}

\author{
Nanda Sadewa ${ }^{1}$ \\ Gerianta Wirawan Yasa ${ }^{2}$ \\ 1.Fakultas Ekonomi dan Bisnis Universitas Udayana (Unud), Bali, Indonesia \\ e-mail: nanda.sadewa94@yahoo.co.id \\ ${ }^{2}$ Fakultas Ekonomi dan Bisnis Universitas Udayana (Unud), Bali, Indonesia
}

\begin{abstract}
ABSTRAK
Penelitian ini bertujuan untuk mengetahui pengaruh corporate governance dan leverage pada biaya keagenan. Penelitian ini dilakukan dalam ruang lingkup perusahaan yang terdaftar di Bursa Efek Indonesia. Pengamatan dilakukan di seluruh sektor perusahaan pada periode 2009-2013. Sampel ditentukan dengan menggunakan metode purposive sampling sehingga 92 sampel diambil sesuai kriteria. Penelitian ini menggunakan regresi linier berganda sebagai teknik analisis data. Hipotesis dalam penelitian ini menyatakan bahwa corporate governance dan leverage berpengaruh negatif pada biaya keagenan. Sebaliknya, hasil penelitian menunjukkan bahwa corporate governance dan leverage berpengaruh positif signifikan pada biaya keagenan. Penelitian ini membuktikan bahwa semakin meningkatnya corporate governance dan leverage dalam suatu perusahaan maka biaya keagenan juga semakin meningkat.
\end{abstract}

Kata kunci: Biaya keagenan, corporate governance, leverage

\section{ABSTRACT}

The purpose of this research is to know the influence of corporate governance and leverage on agency cost. This research is done within the scope of the firms that listed in Indonesia Stock Exchange. Observation is done in all sectors of the firms in 2009-2013. Samples are defined by using purposive sampling method thus 92 samples are obtained that match with criteria. This research uses multivariate regression as analysis technique. The hypothesis of this research said that corporate governance and leverage have a negative influence on agency cost. The result shows that corporate governance and leverage have positive and significant influence on agency cost. This research prove that the increasing of corporate governance and leverage in a firm, agency cost also increased.

Keywords: Agency cost, corporate governance, leverage

\section{PENDAHULUAN}

Konflik keagenan merupakan konflik yang muncul karena adanya kepentingan yang berbeda diantara prinsipal dan agen. Eisenhardt (1989) dikenal membangun asumsi kepentingan yang berbeda antara prinsipal dan agen yang menyebabkan timbulnya konflik keagenan. Timbulnya konflik yaitu ketika prinsipal tidak tahu apa saja yang dilakukan oleh agen. Masalah keagenan ini dapat dibagi menjadi dua kategori. Pertama, dikenal sebagai adverse selection (keputusan merugikan), terjadi jika seorang agen gagal memberikan kemampuannya. Kedua, dikenal sebagai moral hazard, yaitu kondisi lingkungan di mana agen melalaikan tanggung jawab, atau bertindak untuk kepentingannya sendiri sehingga bertentangan dengan kepentingan prinsipal.

Konflik keagenan dapat disebabkan juga oleh karena adanya perbedaan keputusan investasi antara pemegang saham dengan manajer (Bathala et al, 1994). Konflik keagenan dalam suatu perusahaan dapat memicu timbulnya biaya keagenan (agency cost). Biaya keagenan dapat timbul saat kepentingan yang dimiliki agen tidak selaras dengan kepentingan yang dimiliki prinsipal dan mempengaruhi kinerja serta keputusan manajer berdasarkan kepentingan pribadi maupun keputusan pembentengan (entrenchment) yang dapat mengurangi kesejahteraan prinsipal (Jensen dan Meckling, 1976).

Terdapat berbagai cara yang dapat dilakukan oleh pemegang saham untuk mengatasi konflik keagenan dan meminimalkan biaya keagenan tersebut. Salah satunya ialah melalui mekanisme tata kelola perusahaan atau yang biasa dikenal sebagai corporate governance (Fama dan Jensen, 1983). Menurut Linda (2012), mekanisme corporate governance diperlukan untuk mengurangi ketidakefisienan yang timbul dari bahaya moral dan 
pilihan yang buruk dari manajemen perusahaan. Hal ini mendukung penelitian Chtourou et al. (2001) yang menyatakan bahwa prinsip corporate governance yang diaplikasikan secara konsisten dapat mengurangi permasalahan dalam aktivitas rekayasa kinerja yang mengakibatkan laporan keuangan tidak menunjukkan nilai perusahaan yang sebenarnya.

Konflik keagenan yang muncul antara prinsipal dan agen menjunjung penerapan corporate governance yang baik dalam suatu perusahaan yang diharapkan dapat menurunkan potensi tindakan oportunis dari manajemen (Ariwangsa, 2007). Core et al. (1999) menyatakan bahwa perusahaan menghadapi konflik keagenan yang tinggi ketika corporate governance perusahaan tersebut lemah. Perusahaan dengan penerapan corporate governance yang belum maksimal memiliki permasalahan keagenan yang besar (Linda, 2012).

Cara lain yang dapat dilakukan oleh pemegang saham dalam mengatasi konflik keagenan ialah dengan meningkatkan proporsi utang (Jensen dan Meckling, 1976). Peningkatan rasio utang atau dengan kata lain terjadi peningkatan leverage menyebabkan jumlah porsi saham yang akan dijual oleh perusahaan berkurang. Meningkatnya leverage juga dapat mengendalikan penggunaan aliran kas bebas (free cash flow) yang berlebihan oleh manajemen perusahaan. Berdasarkan latar belakang yang telah dijelaskan, rumusan masalah yang dapat diambil ialah bagaimanakah pengaruh corporate governance dan leverage pada biaya keagenan (agency cost).

Beberapa studi empiris telah dilakukan berkaitan dengan biaya keagenan (agency cost) yang ditimbulkan oleh konflik keagenan. Penelitian mengenai biaya keagenan (agency cost) memiliki hasil yang tidak konsisten. Schooley et al. (1994) menggunakan kepemilikan saham sebagai salah satu mekanisme corporate governance dengan hasil berpengaruh negatif terhadap biaya keagenan (agency cost). Purnami (2011) juga melakukan penelitian yang sama namun dengan menggunakan variabel mekanisme yang berbeda, yaitu kepemilikan manajerial dan kepemilikan institusional, serta leverage terhadap biaya keagenan. Hasil yang didapat ialah kepemilikan manajerial berpengaruh negatif terhadap biaya keagenan (agency cost), sedangkan kepemilikan institusional, dan leverage tidak berpengaruh terhadap biaya keagenan (agency cost). Penelitian Purnami (2011) mendukung penelitian yang dilakukan oleh Widanaputra dan Ratnadi (2008) yang menemukan hasil empiris mengenai kepemilikan manajerial yang berpengaruh negatif terhadap biaya keagenan (agency cost).

Sanjaya dan Christianti (2012) melakukan penelitian berkaitan dengan corporate governance dan agency cost. Hasilnya ialah penerapan mekanisme corporate governance dapat menurunkan biaya keagenan. Penelitian tersebut didukung oleh Sudarma dan Putra (2014). Hasil penelitiannya ialah penerapan good corporate governance dapat menurunkan biaya keagenan.

Berdasarkan rumusan masalah yang telah dipaparkan, maka tujuan penelitian ini adalah untuk mengetahui pengaruh corporate governance pada biaya keagenan dan pengaruh leverage pada biaya keagenan. Teori dan konsep yang mendasari dan mendukung landasan berpikir penelitian ini yakni teori keagenan (agency theory). Teori keagenan muncul karena terdapat sebuah kontrak antara pemegang saham dengan pihak manajemen.

Konflik kepentingan antara manajemen (agen) dan pemegang saham (prinsipal) dapat dikurangi dengan suatu mekanisme pengawasan (Jensen dan Meckling, 1976). Oleh karena adanya pengawasan tersebut, perusahaan akan mengeluarkan biaya yang disebut sebagai biaya keagenan (agency cost).

Dalam teori keagenan dikatakan bahwa konflik keagenan timbul karena adanya asimetri informasi antara prinsipal dengan agen. Hal ini disebabkan karena adanya perbedaan kepentingan karena berdasarkan asumsi sifat dasar manusia ialah ingin lebih menguntungkan dirinya sendiri. Untuk mencegah adanya penyimpangan perilaku dan keputusan manajemen dengan tujuan pemegang saham maka diperlukan sebuah mekanisme pengendalian atau tata kelola yang kuat dalam perusahaan.

Corporate governance merupakan suatu sistem yang mengarahkan dan mengendalikan perusahaan untuk meningkatkan keberhasilan dan nilai perusahaan serta memenuhi tujuan stockholder maupun stakeholder. Keefektifan mekanisme corporate governance potensi dalam kaitannya dengan meminimalkan biaya agensi (Linda, 2012). Perusahaan yang menerapkan tata kelola perusahaan yang baik dapat menambah keyakinan bagi stockholder (Sudarma dan Putra, 2014).

Menurut Komite Nasional Kebijakan Governance (KNKG), asas yang diperlukan agar terciptanya good corporate governance pada perusahaan. Asas-asas tersebut, yaitu transparansi, akuntabilitas, responsibilitas, independensi, dan kewajaran dan kesetaraan. 
Peningkatan leverage dapat menambah pengawasan terhadap manajemen sehingga manajemen akan susah untuk bertindak menyimpang dari tujuan perusahaan. Sawir (2004) dalam Purnami (2011) menyatakan bahwa leverage keuangan adalah penggunaan sumber dana yang menimbulkan beban tetap keuangan atau yang biasa disebut sebagai kewajiban.

Menurut Prasetyo (2009), salah satu cara mengurangi konflik keagenan ialah melalui mekanisme tata kelola perusahaan (corporate governance). Sanjaya dan Christianti (2012) mengemukakan bahwa mekanisme tata kelola perusahaan yang baik dapat mengurangi biaya keagenan. Sejalan dengan hasil penelitian yang dilakukan oleh Sudarma dan Putra (2014), bahwa penerapan good corporate governance yang semakin intensif mampu mengurangi biaya keagenan.

$\mathrm{H}_{1}$ : Corporate governance berpengaruh negatif pada agency cost.

Struktur utang dapat berperan sebagai alat untuk memonitor biaya agensi dalam suatu perusahaan (Linda, 2012). Dengan memiliki rasio leverage yang tinggi, pihak kreditur akan lebih mengontrol perusahaan dalam penggunaan dananya sehingga manajemen perusahaan hanya memiliki sedikit kemungkinan untuk melakukan tindakan yang tidak meningkatkan nilai perusahaan. Semakin besar tingkat utang suatu perusahaan maka semakin banyak perusahaan menyediakan kas untuk melunasi bunga dan utangnya sehingga memperkecil dana menganggur (Widanaputra dan Ratnadi, 2008). Selain itu, rasio leverage yang besar dapat mempengaruhi manajer dan menurunkan biaya keagenan melalui ancaman likuiditas yang berdampak pada gaji personal dan reputasi manajer (Yegon et al., 2014). Oleh karena itu, tingginya leverage perusahaan akan meningkatkan pengawasan dan berdampak pada berkurangnya biaya agensi.

$\mathrm{H}_{2}$ : Leverage berpengaruh negatif pada agency cost.

\section{METODE PENELITIAN}

Ruang lingkup penelitian ini adalah perusahaan yang terdaftar di Bursa Efek Indonesia (BEI). Segala data yang dipublikasikan oleh perusahaan di BEI merupakan data yang akurat karena BEI berada dibawah pengawasan Otoritas Jasa Keuangan (OJK) sehingga BEI menjadi salah satu ruang lingkup penelitian yang dapat dipercaya (reliable).
Jenis data dalam penelitian ini ialah menggunakan data kuantitatif. Penelitian ini menggunakan data kuantitatif berupa Corporate Governance Perception Index (CGPI), dan debt to total asset ratio serta selling and general administrative ratio (SGA) yang ada di dalam laporan keuangan perusahaan yang terdaftar di BEI dari tahun 2009 sampai 2013. Data kuantitatif pertama, yaitu indeks CGPI didapatkan dari majalah SWA. Data kuantitatif kedua, yaitu berupa laporan keuangan yang didapatkan dengan mengunduh di website BEI.

Semua sektor perusahaan yang ada di BEI merupakan populasi dalam penelitian ini. Sampel diperoleh berdasarkan kriteria tertentu (purposive sampling). Kriteria pertama ialah perusahaanperusahaan di BEI menyediakan laporan keuangan tahunan (annual report) periode 2009-2013 dan tidak delisting selama periode pengumpulan data. Kriteria kedua ialah perusahaan yang diberi skor CGPI oleh The Indonesian Institute for Corporate Governance (IICG) pada periode 2009-2013. Kriteria ketiga ialah perusahaan memiliki proporsi utang dalam pendanaan perusahaannya dari tahun 2009-2013.

Terdapat satu variabel terikat serta dua variabel bebas, di mana variabel terikat ialah Agency Cost (Y) yang diukur dengan selling and general administrative (SGA). SGA ini merupakan rasio antara biaya operasional dengan jumlah pendapatan. SGA yang tinggi menunjukkan biaya agensi yang tinggi (Linda, 2012). Jika nilai rasio ini tinggi, dapat diartikan bahwa terjadi pengeluaran yang tidak diperlukan seperti pemberian fasilitas berlebih kepada manajer (Piramita, 2012). SGA dapat dirumuskan sebagai berikut:

$$
S G A=\frac{\text { Biaya Operasional }}{\text { Total Penjualan }}
$$

Variabel bebasnya adalah Corporate Governance $\left(\mathrm{X}_{1}\right)$ dan Leverage $\left(\mathrm{X}_{2}\right)$. Corporate governance diukur berdasarkan nilai yang dikeluarkan oleh IICG dan nilai tersebut dikenal dengan sebutan CGPI.

Rasio leverage dalam penelitian ini ialah rasio antara total utang terhadap aktiva (debt to total asset ratio). Debt to total asset ratio dipilih karena rasio tersebut mencerminkan pembiayaan seluruh kekayaan perusahaan melalui utang. Maka ukuran leverage dapat dirumuskan sebagai berikut:

$$
\mathrm{DAR}=\frac{\text { Total Utang }}{\text { Total Aktiva }} \times 100 \%
$$


Tabel 1.

Hasil Statistik Deskriptif

\begin{tabular}{ccccc}
\hline Variabel & Minimum & Maksimum & Rata-Rata & $\begin{array}{c}\text { Deviasi } \\
\text { Standar }\end{array}$ \\
\hline CGPI & 67,390 & 91,910 & 81,910 & 6,460 \\
DAR & 0,176 & 0,950 & 0,613 & 0,245 \\
SGA & 0,027 & 0,747 & 0,278 & 0,204 \\
\hline
\end{tabular}

Sumber: lampiran 1, 2015

Pengamatan dilakukan terhadap laporan keuangan perusahaan yang termasuk dalam BEI dari tahun 2009-2013. Teknik analisis data yang digunakan adalah regresi linier berganda dengan rumus:

$S G A=\alpha+\beta 1 C G P I+\beta 2 D A R+\varepsilon \ldots \ldots \ldots .(3)$

Keterangan:

SGA = Selling and General Administrative Ratio

$\alpha \quad=$ konstanta

$\beta=$ koefisien regresi

CGPI $=$ Corporate Governance Perception Index

$\mathrm{DAR}=$ Debt to Total Assets Ratio

$\varepsilon \quad=$ error

\section{HASIL DAN PEMBAHASAN}

Pengolahan data dilakukan sesuai dengan metode penelitian yang telah dipaparkan. Peneliti menggunakan SPSS 13.0 for Windows untuk mengolah data.

Berdasarkan hasil pengolahan data pada Tabel 1, dapat diketahui bahwa variabel corporate governance memiliki nilai rata-rata 81,910 dengan nilai minimum 67,390 dan nilai maksimum 91,910. Hal ini menunjukkan bahwa perusahaan memiliki ratarata indeks CGPI 81,910 yang menandakan bahwa rata-rata corporate governance perusahaan termasuk ke dalam kategori perusahaan terpercaya (trusted company). Sedangkan deviasi standar dari corporate governance ialah sebesar 6,460 yang besarnya lebih rendah dari rata-rata. Artinya, sebaran data corporate governance sudah merata dan menunjukkan bahwa jarak selisih data satu dengan data lainnya tidak jauh. CGPI dinilai berdasarkan penerapan unsur good corporate governance pada suatu perusahaan. Semakin tinggi skor CGPI yang didapat perusahaan maka semakin tinggi tingkat kepercayaan yang diberikan kepada perusahaan tersebut.

Variabel leverage memiliki nilai rata-rata sebesar 0,613 dengan nilai minimum 0,176 dan nilai maksimum 0,950 . Hal ini menunjukkan bahwa perusahaan ratarata memiliki rasio leverage sebesar $61,3 \%$ yang menandakan bahwa rata-rata $61,3 \%$ nilai kekayaan atau aset perusahaan dibiayai melalui utang perusahaan. Sedangkan deviasi standar dari leverage ialah sebesar 0,245 yang besarnya lebih rendah dari rata-rata. Leverage yang tinggi menimbulkan risiko yang harus ditanggung oleh pihak ketiga semakin besar.

Variabel agency cost memiliki nilai rata-rata sebesar 0,278 dengan nilai minimum 0,027 dan nilai maksimum 0,747. Hal ini menunjukkan bahwa perusahaan rata-rata memiliki rasio biaya keagenan sebesar 27,8\% yang timbul dari diskresi manajerial atau kinerja manajer yang kurang efisien dalam pembiayaan operasional perusahaan. Sedangkan deviasi standar dari biaya keagenan ialah sebesar 0,204 yang besarnya lebih rendah dari rata-rata. Semakin tinggi rasio SGA suatu perusahaan menunjukkan bahwa biaya keagenan yang dikeluarkan oleh perusahaan semakin besar.

Tabel 2.

\section{Hasil Uji Normalitas}

\begin{tabular}{cc}
\hline Kolmogorov-Smirnov Z & 1,268 \\
Asymp. Sig. (2-tailed) & 0,80 \\
\hline
\end{tabular}

Sumber: lampiran 2, 2015

Tabel 2 menjelaskan data memiliki nilai Kolmogorov-Smirnov Z 1,268 dengan nilai signifikansi 0,080 yang lebih besar dari $\alpha=0,05$. Dapat disimpulkan data memiliki distribusi normal dan tentunya penelitian layak untuk dilanjutkan.

Hasil pengolahan data pada Tabel 3 menunjukkan bahwa baik variabel corporate governance maupun variabel leverage memiliki nilai tolerance 0,976 yang lebih besar dari 0,1 dan nilai VIF 1,025 yang lebih kecil dari 10. Hal ini berarti bahwa baik variabel corporate governance maupun variabel leverage sama-sama tidak memiliki korelasi antar variabel independen atau dengan kata lain variabel independen bebas dari multikolinearitas dan penelitian layak diteliti lebih lanjut.

Tabel 3.

Hasil Uji Multikolinearitas

\begin{tabular}{ccc}
\hline Variabel & Tolerance & VIF \\
\hline CGPI & 0,976 & 1,025 \\
DAR & 0,976 & 1,025 \\
\hline
\end{tabular}

Sumber: lampiran 3, 2015 
Tabel 4. Hasil Uji Heteroskedastisitas

\begin{tabular}{cc}
\hline Variabel & Sig. \\
\hline CGPI & 0,341 \\
DAR & 0,058 \\
\hline
\end{tabular}

Sumber: lampiran 4, 2015

Hasil pengolahan data pada Tabel 4 menunjukkan bahwa variabel corporate governance memiliki nilai t 0,958 dengan tingkat signifikansi 0,341 yang lebih besar dari $\alpha=0,05$. Variabel leverage memiliki nilai t $-1,924$ dengan tingkat signifikansi 0,058 yang lebih besar dari $\alpha 5 \%$ atau 0,05 . Hal ini berarti bahwa baik variabel corporate governance maupun variabel leverage memiliki varians residual yang tetap pada setiap pengamatan atau dengan kata lain data kedua variabel bersifat homokedastisitas dan penelitian layak untuk diteliti lebih lanjut.

Hasil pengolahan data Tabel 5 menunjukkan bahwa model regresi memiliki nilai Durbin-Watson 2,030 yang berada diantara du dengan nilai 1,703 dan 4-du dengan nilai 2,297. Nilai du yaitu 1,703 dapat dilihat pada lampiran 2 Tabel Durbin Watson. Dengan kata lain, nilai Durbin-Watson memenuhi korelasi antar pengamatan dalam model regresi atau dengan kata lain penelitian bebas dari autokorelasi dan penelitian layak untuk diteliti lebih lanjut.

Hasil pengolahan data pada Tabel 6 menunjukkan bahwa model regresi memiliki nilai adjusted $R$ square sebesar 0,171. Hal ini berarti bahwa sebesar $17,1 \%$ variabel independen yaitu corporate governance dan leverage dapat menjelaskan varians dari variabel dependen yaitu agency cost. Sedangkan sisanya yaitu $82,9 \%$ dijelaskan oleh faktor lain di luar model.

Tabel 5.

\section{Hasil Uji Autokorelasi}

\begin{tabular}{cc}
\hline Durbin-Watson & 2,030 \\
\hline
\end{tabular}

Sumber: lampiran 3, 2015

Tabel 6. Analisis Koefisien Determinasi

Adjusted R Square $\quad 0,171$

Sumber: lampiran 3, 2015
Tabel 7. Analisis Uji F (Uji Simultan)

\begin{tabular}{cc}
\hline F & 9,974 \\
Sig. & 0,000 \\
\hline
\end{tabular}

Sumber: lampiran 3, 2015

Hasil pengolahan data pada Tabel 7 menunjukkan bahwa model regresi memiliki nilai $\mathrm{F}_{\text {hitung }} 9,974$ dengan tingkat signifikansi 0,000 yang jauh lebih rendah dari $\alpha$ yaitu $5 \%$ atau 0,05 . Hal ini berarti bahwa model regresi yang dibuat sudah tepat/ signifikan dan seluruh variabel independen memiliki pengaruh secara serempak terhadap variabel dependen.Berdasarkan hasil pengolahan data pada Tabel 8, maka model regresi dapat ditulis sebagai berikut:

$S G A=-0,600+0,009 C G P I+0,242 D A R+\varepsilon$

Berdasarkan hasil analisis pada Tabel 8, dapat diketahui bahwa variabel corporate governance memiliki koefisien positif 0,009 dengan $t_{\text {hitung }}$ positif sebesar 2,861. Signifikansi 0,005 berada dibawah $\alpha$ $=0,05$ menunjukkan bahwa pengaruhnya signifikan. Hal ini berarti bahwa corporate governance berpengaruh positif pada biaya keagenan sehingga $\mathrm{H}_{1}$ ditolak. Corporate governance terbukti gagal menjelaskan pengaruh negatifnya pada biaya keagenan sesuai dengan hipotesis.

Fenomena ini dapat dijelaskan melalui sudut pandang teori signaling. Menurut Akerlof (1970), teori signaling menjelaskan bagaimana perusahaan memberikan sinyal-sinyal kepada pengguna laporan keuangan. Sinyal ini berupa informasi mengenai kinerja manajemen dalam mencapai tujuan pemilik perusahaan.

Penilaian indeks CGPI terhadap suatu perusahaan bersifat tidak wajib (volunteer). Perusahaan yang mendaftarkan diri untuk dinilai tata kelola perusahaannya melalui CGPI mengindikasikan adanya pemberian sinyal kepada pengguna laporan keuangan. Perusahaan melakukan hal tersebut untuk memberi sinyal bahwa tata kelola perusahaannya

Tabel 8. Analisis Uji t (Uji Parsial)

\begin{tabular}{cccc}
\hline & Koefisien & T & Sig. \\
\hline$\alpha$ & $-0,600$ & $-2,371$ & 0,020 \\
CGPI & 0,009 & 2,861 & 0,005 \\
DAR & 0,242 & 2,945 & 0,004 \\
\hline
\end{tabular}

Sumber: lampiran 3, 2015 
termasuk ke dalam kategori perusahaan terpercaya (trusted company). Perusahaan akan berusaha untuk mendapatkan nilai CGPI yang tinggi dengan menerapkan konsep good corporate governance. Good corporate governance memiliki unsur-unsur tersendiri untuk dapat diterapkan, yaitu transparency, accountability, responsibility, independency, dan fairness. Penerapan unsur good corporate governance tersebut membutuhkan biaya sehingga perusahaan yang menginginkan tata kelola perusahaannya semakin baik akan mengeluarkan biaya yang semakin tinggi.

Berdasarkan hasil analisis pada Tabel 8, dapat diketahui bahwa variabel leverage memiliki koefisien positif sebesar 0,242 dengan $t_{\text {hitung }}$ positif sebesar 2,945. Signifikansi 0,004 berada dibawah $\alpha=0,05$ menunjukkan bahwa pengaruhnya signifikan. Hal ini berarti bahwa leverage berpengaruh positif dan signifikan pada biaya keagenan sehingga $\mathrm{H}_{2}$ ditolak. Leverage terbukti gagal menjelaskan pengaruh negatifnya pada biaya keagenan sesuai dengan hipotesis.

Leverage mencerminkan besarnya rasio struktur utang baik jangka pendek maupun jangka panjang yang dimiliki oleh suatu perusahaan. Perusahaan dengan leverage tinggi tidak terlepas dari besarnya risiko yang harus ditanggung oleh pihak ketiga. Risiko tersebut berupa kemungkinan perusahaan tidak mampu melunasi biaya tetap, baik berupa bunga maupun pokok pinjamannya. Namun sisi positifnya, leverage yang tinggi menambah kesempatan bagi perusahaan untuk meningkatkan nilai perusahaannya. Hal ini dikarenakan perusahaan mendapatkan dana yang besar untuk melakukan berbagai aktivitas. Peningkatan nilai perusahaan pada sampel penelitian ini seiring dengan peningkatan kebutuhan biaya, salah satunya ialah biaya bonus atau kompensasi manajemen. Biaya ini dikeluarkan karena manajemen mampu menggunakan sumber dana melalui utang secara efektif dan efisien.

Sampel dalam penelitian ini sebagian besar menerbitkan obligasi untuk mendapatkan sumber dana tambahan. Untuk memberikan sinyal positif kepada pembeli obligasi bahwa obligasi tersebut dapat dipercaya, perusahaan mengeluarkan biaya pemeringkat terhadap obligasi yang diterbitkan. Mayoritas sampel perusahaan dalam penelitian ini menggunakan jasa PT PEFINDO untuk memberikan peringkat terhadap obligasinya. PT PEFINDO merupakan salah satu lembaga pemeringkat obligasi yang terpercaya di Indonesia karena PT PEFINDO telah terafiliasi oleh Standard \& Poor's Rating
Agency yang merupakan salah satu perusahaan pemeringkat terpercaya di dunia.

\section{SIMPULAN}

Corporate governance berpengaruh positif dan signifikan pada biaya keagenan (agency cost) sehingga $\mathrm{H}_{1}$ ditolak. Artinya, semakin tinggi corporate governance perusahaan, maka semakin tinggi pula biaya keagenan yang dikeluarkan oleh perusahaan. Perusahaan ingin mencapai skor CGPI yang semakin tinggi sebagai sinyal positif kepada investor bahwa perusahaannya termasuk ke dalam kategori trusted company. Pemberian sinyal tersebut dapat dilakukan dengan menggunakan jasa auditor bereputasi tinggi. Penggunaan jasa auditor bereputasi tinggi menyebabkan biaya keagenan dalam suatu perusahaan meningkat.

Leverage berpengaruh positif dan signifikan pada biaya keagenan (agency cost) sehingga $\mathrm{H}_{2}$ ditolak. Artinya, semakin tinggi leverage keuangan suatu perusahaan maka semakin tinggi pula biaya keagenan yang dikeluarkan oleh perusahaan tersebut. Penggunaan leverage yang tinggi dalam suatu perusahaan menyebabkan peningkatan risiko yang harus ditanggung oleh pihak ketiga. Perusahaan memberikan kompensasi lebih kepada manajemen karena manajemen telah bekerja secara efektif dan efisien dalam menggunakan utang. Selain itu, perusahaan menggunakan jasa pemeringkat obligasi yang terpercaya untuk memberikan sinyal positif bahwa obligasinya aman dan dapat dipercaya. Penggunaan jasa pemeringkat obligasi yang terpercaya juga menimbulkan biaya tambahan dalam suatu perusahaan.

Keterbatasan penelitian ini hanya menggunakan proksi selling and general administrative (SGA) sebagai alat ukur biaya keagenan. Proksi SGA ini hanya mencerminkan biaya keagenan secara umum (general).

Populasi dalam penelitian ini ialah seluruh sektor industri perusahaan yang terdaftar di Bursa Efek Indonesia sehingga terjadi perbedaan pada besarnya biaya keagenan dalam suatu perusahaan.

Penelitian selanjutnya disarankan menggunakan proksi lain sebagai alat ukur biaya keagenan untuk memperkuat kejelasan pengukuran biaya keagenan. Alat ukur biaya keagenan pada penelitian selanjutnya diharapkan dapat mencerminkan biaya keagenan secara lebih spesifik ke arah monitoring cost, bonding cost, dan residual loss. Alat ukur yang diduga dapat mencerminkan ketiga biaya keagenan 
tersebut ialah jasa profesional untuk monitoring cost, kompensasi manajemen untuk bonding cost, dan biaya perjalanan dinas untuk residual loss.

Penelitian lebih lanjut disarankan lebih mengontrol jenis industri yang akan digunakan sebagai populasi penelitian. Pengontrolan jenis industri dapat mempersempit jarak data sehingga besaran biaya keagenan bersifat lebih tajam dan akurat.

\section{REFERENSI}

Akerlof, George A. 1970. The Market for Lemons: Quality Uncertainty and The Market Mechanism. Quaterly Journal of Economics. 83(4): h:488-500.

Ariwangsa, I Putu Kamyarta. 2007. Pengaruh Mekanisme Corporate Governance Terhadap Biaya Hutang. Skripsi. Fakultas Ekonomi Unversitas Airlangga, Surabaya.

Bathala, C.T., K.P. Moon, dan R.P. Rao. 1994. Managerial Ownership, Debt Policy, and The Impact of Institutional Holding: An Agency Perspective. Financial Management, 23(3): h:3850.

Chtourou, Sonda Marrakchi, Jean Bedard, dan Lucie Courteau. 2001. Corporate Governance and Earnings Management. Workingpaper, April.

Clarkson, M.B.E. 1995. A stakeholder framework for analyzing and evaluating corporate social performance. Academy of Management Review, 20(1): h:92-117.

Core, J., R. Holthausen, dan D. Larcker. 1999. Corporate Governance, Chief Executive Officer Compensation, and Firm Performance. Journal of Financial Economics. 51: h:371 - 406.

Denis, D.K., dan J.J. McConnell. 2003. International Corporate Governance. Journal of Financial and Qualitative Analysis. 38: h:1-36.

Destriana, Nicken. 2011. Masalah dan Biaya Keagenan. Jurnal Media Bisnis. STIE Trisakti.

Eisenhardt, K.M. 1989. Agency Theory: An Assessment and Review. Academy of Management Review, 14(1): h:57-74.

Fama, E.F., and M. Jensen. 1983. Separation of Ownership and Control. Journal of Law and Economics. 88: h:301-325.

Gul, S., M. Sajid, N. Razzaq, F. Afzal. 2014. Agency Cost, Corporate Governance and Ownership Structure (The Case of Pakistan). International Journal of Business and Social Science, 3(9): $\mathrm{h}: 268-277$.

Jensen, M. C. 1986. Agency Costs of free cash flow, corporate finance and takeovers. American Economic Review. 76: h:323-39.
Jensen, M.C. dan W.H. Meckling. 1976. Theory of The Firm: Managerial Behavior, Agency Cost and Ownership Structure. Journal of Financial Economics, 3(4): h:305-360.

Komite Nasional Kebijakan Governance. 2006. Pedoman Umum Good Corporate Governance. Jakarta.

Krisnauli. 2014. Pengaruh Mekanisme Tata Kelola Perusahaan dan Struktur Kepemilikan terhadap Agency Cost. Skripsi. Universitas Diponegoro.

Linda. 2012. Mekanisme Corporate Governance dan Biaya Agensi. Skripsi. Fakultas Ekonomika dan Bisnis Universitas Syiah Kuala, Aceh.

Messier, William F., Steven M. Glover, Douglas F. Prawitt. 2006. Auditing and Assurance ServicesA Systemic Approach. Jakarta: Salemba Empat.

Piramita, Santi. 2012. Analisis Pengaruh Free Cash Flow terhadap Agency Cost dan Kinerja Keuangan. Skripsi. Universitas Indonesia.

Prasetyo, Arief. 2009. Corporate Governance, Kebijakan Dividen dan Nilai Perusahaan. Skripsi. Fakultas Ekonomi Universitas Trisakti.

Purnami, Ketut. 2011. Pengaruh Kepemilikan Manajerial, Kepemilikan Institusional, Kebijakan Dividen, dan Leverage pada Biaya Keagenan (Agency Cost). Thesis. Universitas Udayana.

Sanjaya, I.P.S., dan I. Christianti. 2012. Corporate Governance and Agency Cost: Case in Indonesia. Dalam 2nd International Conference on Business, Economics, Management and Behavioral Sciences. h:112-118

Schooley, Diane K. dan L. Dwayne Barney Jr. 1994. Using Dividend Policy and Managerial Ownership to Reduce Agency Cost. The Journal of Financial Research, 17: h:363-373.

Scott, William. 2000. Financial Accounting Theory, Second Edition. Canada: Prentice Hall.

Sudarma, P.M., dan I.W., Putra. 2014. Pengaruh Good Corporate Governance Pada Biaya Keagenan. Ejurnal Akuntansi Universitas Udayana, 9(3): h:591-607.

Sugiyono. 2010. Metode Penelitian Kuantitatif, Kualitatif dan $R \& D$. Bandung: Alfabeta.

Sugiyono. 2014. Metode Penelitian Bisnis. Bandung: Alfabeta.

Syakhroza, Akhmad. 2003. Teori Corporate Governance. Usahawan, No. 08, Th XXXII, Agustus.

Utama, Made Suyana. 2014. Aplikasi Analisis Kuantitatif, Edisi Kedelapan. Universitas Udayana.

Widanaputra, A. A. G. P. dan Ratnadi, Ni Made Dwi. 2008. Pengaruh Kebijakan Dividen dan Kepemilikan Manajerial Terhadap Kos Keagenan. 
AUDI Jurnal Akuntansi dan Bisnis, 3(2): h:186197.

Yegon, C., J. Sang, J. Kirui. 2014. The Impact of Corporate Governance on Agency Cost: Empirical
Analysis of Quoted Services Firms in Kenya. Research Journal of Finance and Accounting, 5(12): h:145-154.

\section{LAMPIRAN}

\section{Hasil Analisis Deskriptif}

1.

Descriptive Statistics

\begin{tabular}{|l|r|r|r|r|r|}
\hline & \multicolumn{1}{|c|}{$\mathrm{N}$} & Minimum & Maximum & \multicolumn{1}{c|}{ Mean } & Std. Deviation \\
\hline CGPI & 88 & 67.39 & 91.91 & 81.91 & 6.46 \\
DAR & 88 & .1759 & .9500 & .6127 & .2455 \\
SGA & 88 & .0273 & .7468 & .2779 & .2038 \\
Valid N (listwise) & 88 & & & & \\
\hline
\end{tabular}

\section{Hasil Uji Normalitas}

One-Sample Kolmogorov-Smirnov Test

\begin{tabular}{|ll|r|}
\hline & & $\begin{array}{r}\text { Unstandardiz } \\
\text { ed Residual }\end{array}$ \\
\hline $\mathrm{N}$ & & 88 \\
Normal Parameters $\mathrm{a}, \mathrm{b}$ & Mean & .0000000 \\
& Std. Deviation & .18345035 \\
Most Extreme & Absolute & .135 \\
Differences & Positive & .135 \\
& Negative & .069 \\
Kolmogorov-Smirnov Z & & 1.268 \\
Asymp. Sig. (2-tailed) & & .080 \\
\hline
\end{tabular}

a. Test distribution is Normal.

b. Calculated from data.

3. Hasil Uji Autokorelasi, Uji Multikolinearitas, Koefisien Regresi, Uji Simultan, dan Uji Parsial

Variables Entered/Removed

\begin{tabular}{|l|c|c|c|}
\hline Model & $\begin{array}{c}\text { Variables } \\
\text { Entered }\end{array}$ & $\begin{array}{c}\text { Variables } \\
\text { Removed }\end{array}$ & Method \\
\hline 1 & DAR, CGP耳 &. & Enter \\
\hline
\end{tabular}

a. All requested variables entered.

b. Dependent Variable: SGA 
Model Summary

\begin{tabular}{|l|r|r|r|r|r|}
\hline Model & $\mathrm{R}$ & R Square & $\begin{array}{c}\text { Adjusted } \\
\text { R Square }\end{array}$ & $\begin{array}{c}\text { Std. Error of } \\
\text { the Estimate }\end{array}$ & $\begin{array}{c}\text { Durbin- } \\
\text { Watson }\end{array}$ \\
\hline 1 & $.436^{\mathrm{a}}$ & .190 & .171 & .1855960 & 2.030 \\
\hline
\end{tabular}

a. Predictors: (Constant), DAR, CGPI

b. Dependent Variable: SGA

ANOVA

\begin{tabular}{|ll|r|r|r|r|r|}
\hline Model & & \multicolumn{1}{|c|}{$\begin{array}{c}\text { Sum of } \\
\text { Squares }\end{array}$} & df & Mean Square & F & Sig. \\
\hline 1 & Regression & .687 & 2 & .344 & 9.974 & $.000^{\mathrm{a}}$ \\
& Residual & 2.928 & 85 & .034 & & \\
& Total & 3.615 & 87 & & & \\
\hline
\end{tabular}

a. Predictors: (Constant), DAR, CGPI

b. Dependent Variable: SGA

Coefficients $^{\mathrm{a}}$

\begin{tabular}{|c|c|c|c|c|c|c|c|c|}
\hline \multirow{2}{*}{\multicolumn{2}{|c|}{ Model }} & \multicolumn{2}{|c|}{$\begin{array}{l}\text { Unstandardized } \\
\text { Coefficients }\end{array}$} & \multirow{2}{*}{$\begin{array}{c}\begin{array}{c}\text { Standardized } \\
\text { Coefficients }\end{array} \\
\text { Beta }\end{array}$} & \multirow[b]{2}{*}{$\mathrm{t}$} & \multirow[b]{2}{*}{ Sig. } & \multicolumn{2}{|c|}{ Collinearity Statistics } \\
\hline & & $\mathrm{B}$ & Std. Error & & & & Tolerance & VIF \\
\hline \multirow[t]{3}{*}{1} & (Constant) & -.600 & .253 & & -2.371 & .020 & & \\
\hline & CGPI & .009 & .003 & .283 & 2.861 & .005 & .976 & 1.025 \\
\hline & DAR & .242 & .082 & .291 & 2.945 & .004 & .976 & 1.025 \\
\hline
\end{tabular}

a. Dependent Variable: SGA

\section{Coefficient Correlations}

\begin{tabular}{|lll|r|r|}
\hline Model & & & \multicolumn{1}{c|}{ DAR } & \multicolumn{1}{c|}{ CGPI } \\
\hline 1 & Correlations & DAR & 1.000 & -.155 \\
& & CGPI & -.155 & 1.000 \\
\cline { 3 - 5 } & Covariances & DAR & .007 & $-4.0 \mathrm{E}-005$ \\
& & CGPI & $-4.0 \mathrm{E}-005$ & $9.71 \mathrm{E}-006$ \\
\hline
\end{tabular}

a. Dependent Variable: SGA

\section{Collinearity Diagnostics}

\begin{tabular}{|c|c|c|c|c|c|c|}
\hline \multirow[b]{2}{*}{ Model } & \multirow[b]{2}{*}{ Dimension } & \multirow[b]{2}{*}{ Eigenvalue } & \multirow{2}{*}{$\begin{array}{l}\text { Condition } \\
\text { Index }\end{array}$} & \multicolumn{3}{|c|}{ Variance Proportions } \\
\hline & & & & (Constant) & CGPI & DAR \\
\hline \multirow[t]{3}{*}{1} & 1 & 2.905 & 1.000 & .00 & .00 & .01 \\
\hline & 2 & .092 & 5.612 & .01 & .01 & .98 \\
\hline & 3 & .003 & 30.850 & .99 & .99 & .00 \\
\hline
\end{tabular}

a. Dependent Variable: SGA

Residuals Statistics ${ }^{\mathrm{a}}$

\begin{tabular}{|l|r|r|r|r|r|}
\hline & \multicolumn{1}{|c|}{ Minimum } & \multicolumn{1}{|c|}{ Maximum } & \multicolumn{1}{c|}{ Mean } & Std. Deviation & $\mathrm{N}$ \\
\hline Predicted Value & .099457 & .435903 & .277915 & .0888695 & 88 \\
Residual & -.3084754 & .5882906 & .0000000 & .1834504 & 88 \\
Std. Predicted Value & -2.008 & 1.778 & .000 & 1.000 & 88 \\
Std. Residual & -1.662 & 3.170 & .000 & .988 & 88 \\
\hline
\end{tabular}

a. Dependent Variable: SGA 


\section{Hasil Uji Heteroskedastisitas}

Variables Entered/Removed

\begin{tabular}{|l|l|l|l|}
\hline Model & $\begin{array}{c}\text { Variables } \\
\text { Entered }\end{array}$ & $\begin{array}{c}\text { Variables } \\
\text { Removed }\end{array}$ & Method \\
\hline 1 & DAR, CGPP &. & Enter \\
\hline
\end{tabular}

a. All requested variables entered.

b. Dependent Variable: ABSRES

\section{Model Summary}

\begin{tabular}{|l|r|r|r|r|}
\hline Model & $\mathrm{R}$ & R Square & $\begin{array}{c}\text { Adjusted } \\
\text { R Square }\end{array}$ & $\begin{array}{r}\text { Std. Error of } \\
\text { the Estimate }\end{array}$ \\
\hline 1 & $.216^{\mathrm{a}}$ & .047 & .024 & .11466 \\
\hline
\end{tabular}

a. Predictors: (Constant), DAR, CGPI

\section{ANOVA}

\begin{tabular}{|ll|r|r|r|r|l|}
\hline \multicolumn{1}{|c|}{} & \multicolumn{1}{c|}{$\begin{array}{c}\text { Sum of } \\
\text { Model }\end{array}$} & Squares & df & Mean Square & F & Sig. \\
\hline 1 & Regression & .055 & 2 & .027 & 2.074 & $.132^{\mathrm{a}}$ \\
& Residual & 1.117 & 85 & .013 & & \\
& Total & 1.172 & 87 & & & \\
\hline
\end{tabular}

a. Predictors: (Constant), DAR, CGPI

b. Dependent Variable: ABSRES

Coefficients $^{\mathrm{a}}$

\begin{tabular}{|rl|r|r|r|r|r|}
\hline \multirow{2}{*}{ Model } & \multicolumn{2}{|c|}{$\begin{array}{c}\text { Unstandardized } \\
\text { Coefficients }\end{array}$} & \multicolumn{2}{c|}{$\begin{array}{c}\text { Standardized } \\
\text { Coefficients }\end{array}$} & \multicolumn{2}{|c|}{} \\
\cline { 3 - 5 } & \multicolumn{1}{|c|}{$\mathrm{B}$} & Std. Error & \multicolumn{1}{|c|}{ Beta } & \multicolumn{1}{c|}{$\mathrm{t}$} & \multicolumn{1}{c|}{ Sig. } \\
\hline 1 & (Constant) & .050 & .156 & & .319 & .751 \\
& CGPI & .002 & .002 & .103 & .958 & .341 \\
& DAR & -.098 & .051 & -.206 & -1.924 & .058 \\
\hline
\end{tabular}

a. Dependent Variable: ABSRES 


\section{Tabel Durbin-Watson}

Tabel Durbin-Watson (DW), $\alpha=5 \%$

\begin{tabular}{|c|c|c|c|c|c|c|c|c|c|c|}
\hline & \multicolumn{2}{|c|}{$\mathrm{k}=1$} & \multicolumn{2}{|c|}{$\mathrm{k}=2$} & \multicolumn{2}{|c|}{$\mathrm{k}=3$} & \multicolumn{2}{|c|}{$\mathrm{k}=4$} & \multicolumn{2}{|c|}{$\mathrm{k}=5$} \\
\hline $\mathrm{n}$ & $\mathrm{dL}$ & $\mathrm{dU}$ & $\mathrm{dL}$ & $\mathrm{dU}$ & $\mathrm{dL}$ & $\mathrm{dU}$ & $\mathrm{dL}$ & $\mathrm{dU}$ & $\mathrm{dL}$ & $\mathrm{dU}$ \\
\hline 71 & 1.5865 & 1.6435 & 1.5577 & 1.6733 & 1.5284 & 1.7041 & 1.4987 & 1.7358 & 1.4685 & 1.7685 \\
\hline 72 & 1.5895 & 1.6457 & 1.5611 & 1.6751 & 1.5323 & 1.7054 & 1.5029 & 1.7366 & 1.4732 & 1.7688 \\
\hline 73 & 1.5924 & 1.6479 & 1.5645 & 1.6768 & 1.5360 & 1.7067 & 1.5071 & 1.7375 & 1.4778 & 1.7691 \\
\hline 74 & 1.5953 & 1.6500 & 1.5677 & 1.6785 & 1.5397 & 1.7079 & 1.5112 & 1.7383 & 1.4822 & 1.7694 \\
\hline 75 & 1.5981 & 1.6521 & 1.5709 & 1.6802 & 1.5432 & 1.7092 & 1.5151 & 1.7390 & 1.4866 & 1.7698 \\
\hline 76 & 1.6009 & 1.6541 & 1.5740 & 1.6819 & 1.5467 & 1.7104 & 1.5190 & 1.7399 & 1.4909 & 1.7701 \\
\hline 77 & 1.6036 & 1.6561 & 1.5771 & 1.6835 & 1.5502 & 1.7117 & 1.5228 & 1.7407 & 1.4950 & 1.7704 \\
\hline 78 & 1.6063 & 1.6581 & 1.5801 & 1.6851 & 1.5535 & 1.7129 & 1.5265 & 1.7415 & 1.4991 & 1.7708 \\
\hline 79 & 1.6089 & 1.6601 & 1.5830 & 1.6867 & 1.5568 & 1.7141 & 1.5302 & 1.7423 & 1.5031 & 1.7712 \\
\hline 80 & 1.6114 & 1.6620 & 1.5859 & 1.6882 & 1.5600 & 1.7153 & 1.5337 & 1.7430 & 1.5070 & 1.7716 \\
\hline 81 & 1.6139 & 1.6639 & 1.5888 & 1.6898 & 1.5632 & 1.7164 & 1.5372 & 1.7438 & 1.5109 & 1.7720 \\
\hline 82 & 1.6164 & 1.6657 & 1.5915 & 1.6913 & 1.5663 & 1.7176 & 1.5406 & 1.7446 & 1.5146 & 1.7724 \\
\hline 83 & 1.6188 & 1.6675 & 1.5942 & 1.6928 & 1.5693 & 1.7187 & 1.5440 & 1.7454 & 1.5183 & 1.7728 \\
\hline 84 & 1.6212 & 1.6693 & 1.5969 & 1.6942 & 1.5723 & 1.7199 & 1.5472 & 1.7462 & 1.5219 & 1.7732 \\
\hline 85 & 1.6235 & 1.6711 & 1.5995 & 1.6957 & 1.5752 & 1.7210 & 1.5505 & 1.7470 & 1.5254 & 1.7736 \\
\hline 86 & 1.6258 & 1.6728 & 1.6021 & 1.6971 & 1.5780 & 1.7221 & 1.5536 & 1.7478 & 1.5289 & 1.7740 \\
\hline 87 & 1.6280 & 1.6745 & 1.6046 & 1.6985 & 1.5808 & 1.7232 & 1.5567 & 1.7485 & 1.5322 & 1.7745 \\
\hline 88 & 1.6302 & 1.6762 & 1.6071 & 1.6999 & 1.5836 & 1.7243 & 1.5597 & 1.7493 & 1.5356 & 1.7749 \\
\hline 89 & 1.6324 & 1.6778 & 1.6095 & 1.7013 & 1.5863 & 1.7254 & 1.5627 & 1.7501 & 1.5388 & 1.7754 \\
\hline 90 & 1.6345 & 1.6794 & 1.6119 & 1.7026 & 1.5889 & 1.7264 & 1.5656 & 1.7508 & 1.5420 & 1.7758 \\
\hline 91 & 1.6366 & 1.6810 & 1.6143 & 1.7040 & 1.5915 & 1.7275 & 1.5685 & 1.7516 & 1.5452 & 1.7763 \\
\hline 92 & 1.6387 & 1.6826 & 1.6166 & 1.7053 & 1.5941 & 1.7285 & 1.5713 & 1.7523 & 1.5482 & 1.7767 \\
\hline 93 & 1.6407 & 1.6841 & 1.6188 & 1.7066 & 1.5966 & 1.7295 & 1.5741 & 1.7531 & 1.5513 & 1.7772 \\
\hline 94 & 1.6427 & 1.6857 & 1.6211 & 1.7078 & 1.5991 & 1.7306 & 1.5768 & 1.7538 & 1.5542 & 1.7776 \\
\hline 95 & 1.6447 & 1.6872 & 1.6233 & 1.7091 & 1.6015 & 1.7316 & 1.5795 & 1.7546 & 1.5572 & 1.7781 \\
\hline 96 & 1.6466 & 1.6887 & 1.6254 & 1.7103 & 1.6039 & 1.7326 & 1.5821 & 1.7553 & 1.5600 & 1.7785 \\
\hline 97 & 1.6485 & 1.6901 & 1.6275 & 1.7116 & 1.6063 & 1.7335 & 1.5847 & 1.7560 & 1.5628 & 1.7790 \\
\hline 98 & 1.6504 & 1.6916 & 1.6296 & 1.7128 & 1.6086 & 1.7345 & 1.5872 & 1.7567 & 1.5656 & 1.7795 \\
\hline 99 & 1.6522 & 1.6930 & 1.6317 & 1.7140 & 1.6108 & 1.7355 & 1.5897 & 1.7575 & 1.5683 & 1.7799 \\
\hline 100 & 1.6540 & 1.6944 & 1.6337 & 1.7152 & 1.6131 & 1.7364 & 1.5922 & 1.7582 & 1.5710 & 1.7804 \\
\hline
\end{tabular}

Keterangan:

$\mathrm{n}=$ jumlah sampel

$\mathrm{k}=$ jumlah prediktor (variabel independen) 